\title{
PERDAGANGAN UBIKAYU INDONESIA DI PASAR DUNIA \\ (Indonesia Cassava Trade in World Market)
}

\author{
Putri Suci Asriani \\ Jurusan Sosial Ekonomi Pertanian \\ Fakultas Pertanian Universitas Bengkulu \\ putriasriani@yahoo.co.id
}

\begin{abstract}
There are lack of information andmisunderstanding, amongeconomic agents in agriculture farming system related to cassava potencies as food, feed, and industrial resources in agribusiness system. There are, among others, due to assymetric information system for economic potential of cassava marketing system (export and domestic market) in Indonesia, as well as, the information of production and potencies of cassava market in Indonesia, export and domestic market. Economic strategic to develop strive the cassava productivity is feasible to fulfill export and domestic requirement. Information in production allocation and marketing system for export and domestic consumption of cassava will be useful to design strategies for the product development in order to support food security.
\end{abstract}

Key words: Cassava; Production; Potencies; Export and domestic marketing system.

\section{PENDAHULUAN}

Aktivitas ekspor produk ubikayu ke negara-negara non Uni Eropa berkembang sejak pertengahan tahun 1980-an. Hal tersebut didasarkan pada hasil kebijakan ekspor Thailand yang menambah jumlah eksportir untuk mengakses pasar Uni Eropa guna memenuhi kuota yang ditetapkan, walaupun oleh pihak Uni Eropa telah diatur untuk menjual pellets ke negara tujuan lainnya. Sebagai hasilnya, aktivitas ekspor negara-negara lainnya seperti Indonesia dan China secara signifikan memperluas pasar produk ubikayunya.

Dengan semakin terbukanya pasar perdagangan ubikayu dunia maka tingkat kompetisi pasar yang harus dihadapi Indonesia menjadi semakin tinggi. Untuk pasar ekspor, beberapa negara maju di Eropa, Amerika, dan Australia banyak memanfaatkan ubikayu sebagai sumber bahan baku industri pakan, sedangkan di beberapa negara Asia seperti China, Jepang, Malaysia, Korea, Philipina, dan Singapura ubikayu banyak dimanfaatkan sebagai bahan baku industri pangan, pakan dan energi. Kekuatan daya saing produk diharapkan 
dapat dijadikan dasar penentuan arah pasar, baik ekspor maupun impor, yang paling berdaya saing dan efisien.

Dari rata-rata ekspor ubikayu Indonesia pada periode 2002-2003, ubikayu Indonesia paling banyak diekspor ke negara China $(67 \%)$ kemudian diikuti dengan Taiwan (9\%), Malaysia (8\%), Jepang (6\%), dan sisanya ke negara lainnya. Pada aktivitas pemasarannya, sebagai bahan baku industri maupun bahan pangan/pakan, ubikayu belum memiliki kesepakatan harga dasar. Dengan merujuk pada pendekatan strategi pengembangan ekspor ubikayu melalui pengembangan kombinasi comparative advantage dan competitive advantage, maka arah perdagangan ubikayu Indonesia perlu ditetapkan mengingat semakin tingginya tingkat persaingan global yang akan dihadapi.

Dari sisi impor, sejak tahun 1992, Indonesia secara rutin mengimpor cassava starch dari Thailand sebagai eksportir utama ubikayu Indonesia. Kondisi ini kurang menguntungkan petani ubikayu Indonesia, karena harga impor cassava starch yang murah akan mempengaruhi harga jual ubikayu Indonesia dengan tingkat kompetitif yang rendah. Hal tersebut harus mendapatkan perhatian khusus dari berbagai pihak yang berkepentingan langsung maupun tidak langsung dengan pengembangan perubikayuan di Indonesia, sebab Indonesia sebagai negara produsen ubikayu dunia terbesar ketiga dengan tingkat produktivitas tinggi, dalam kurun waktu tahun 1999-2004 menduduki posisi importir terbesar ketiga setelah China dan Jepang.

Dengan didasarkan pada kondisi aktivitas ekspor dan impor ubikayu Indonesia di pasar dunia tersebut, maka perlu dipaparkan deskripsi perdagangan ubikayu Indonesia di pasar dunia sehingga dapat diketahui bentuk perdagangan yang terjadi.

\section{PRODUKSI UBIKAYU INDONESIA}

Ubikayu sebagai komoditas sekunder dalam sistem bahan pokok untuk konsumsi masih sering dianggap sebagai usaha sampingan sehingga pengembangannya belum dilakukan secara intensif. Namun, dari sisi jumlah produksi jika dibandingkan dengan komoditas sekunder dalam sistem bahan pokok untuk konsumsi lainnya, ubikayu menempati posisi pertama (Tabel 1).

Berdasarkan perbandingan luas panen, produktivitas, dan produksi ubikayu Indonesia (Faostat, 2006), diketahui bahwa tingginya jumlah produksi tersebut lebih disebabkan oleh peningkatan produktivitas daripada peningkatan luas panen. Pertumbuhan luas panen pada lima tahun terakhir yang rata-rata 
ISSN: 1412-8837

adalah negatif 0,32 persen mampu memproduksi ubikayu dengan pertumbuhan 4,52 persen pada tingkat produktivitas 0,67 persen.

Tabel 1. Produksi Tanaman Pangan Sekunder di Indonesia

\begin{tabular}{ccccccc}
\hline Tahun & $\begin{array}{c}\text { Jagung } \\
\text { (Ton) }\end{array}$ & $\begin{array}{c}\text { Kedelai } \\
\text { (Ton) }\end{array}$ & $\begin{array}{c}\text { Kacang } \\
\text { Tanah }(\text { Ton })\end{array}$ & $\begin{array}{c}\text { Kacang Hijau } \\
\text { (Ton) }\end{array}$ & $\begin{array}{c}\text { Ubikayu } \\
\text { (Ton) }\end{array}$ & $\begin{array}{c}\text { Ubi Jalar } \\
\text { (Ton) }\end{array}$ \\
\hline 2002 & 9654105 & 673056 & 718071 & 288089 & 16913104 & 1771642 \\
2003 & 10886442 & 671600 & 785526 & 335224 & 18523800 & 1991478 \\
2004 & 11225243 & 723483 & 837495 & 310412 & 19264000 & 1901802 \\
2005 & 12523894 & 808353 & 836295 & 320963 & 19321183 & 1856969 \\
$\left.2006^{*}\right)$ & 12136798 & 780880 & 839970 & 334200 & 19907304 & 1805431 \\
\hline
\end{tabular}

*angka estimasi

Sumber: Food Crops Statistics (2007), diolah.

Penyebaran tanaman ubikayu meluas ke semua propinsi di Indonesia. Pada tahun 2003 propinsi-propinsi yang merupakan sentra produksi komoditas ubikayu adalah Lampung, Jawa Timur, Jawa Tengah, Jawa Barat, dan Daerah Istimewa Yogyakarta (Tabel 2). Tanaman ubikayu tahan dan mampu produktif pada lahan dengan kapasitas nutrisi tanah yang rendah, namun demikian sistem irigasi dan kondisi curah hujan yang tinggi serta penggunaan pupuk tetap harus diperhatikan dengan baik guna mencapai tingkat produktivitas yang tinggi (Plucknett, et.al., 1998 dalam FAO and IFAD, 2004).

Tabel 2. Luas Panen, Hasil Per Hektar, dan Produksi Ubikayu Indonesia di Beberapa Sentra Produksi Pada Tahun 2003

\begin{tabular}{clrcr}
\hline No & \multicolumn{1}{c}{ Propinsi } & $\begin{array}{c}\text { Luas Panen } \\
\text { (Hektar) }\end{array}$ & $\begin{array}{c}\text { Produktivitas } \\
\text { (Ton/Ha) }\end{array}$ & $\begin{array}{c}\text { Produksi } \\
\text { (Ton) }\end{array}$ \\
\hline 1. & Lampung & 298.989 & 16,7 & 4.984 .616 \\
2. & Jawa Timur & 240.493 & 15,7 & 3.786 .882 \\
3. & Jawa Tengah & 215.374 & 16,1 & 3.469 .795 \\
4. & Jawa Barat & 114.853 & 14,4 & 1.651 .879 \\
5. & Nusa Tenggara Timur & 80.330 & 10,7 & 861.620 \\
6. & D.I. Yogyakarta & 59.270 & 12,9 & 764.409 \\
7. & Sulawesi Selatan & 40.808 & 14,5 & 590.717 \\
8. & Sulawesi Utara & 33.452 & 12,3 & 411.990 \\
9. & Sulawesi Tenggara & 15.174 & 13,9 & 210.742 \\
10. & Kalimantan Barat & 16.526 & 14,1 & 233.340 \\
\hline
\end{tabular}

Sumber: Biro Pusat Statistik RI (2005) diolah. 
Ubikayu potensial sebagai usahatani penunjang ketahanan pangan. Hasil olahan ubikayu dapat dijadikan sebagai buffer stock pangan, hal tersebut sudah dilakukan oleh beberapa daerah di Indonesia yang menjadikan ubikayu sebagai bahan pangan, yaitu dalam bentuk chips (gaplek), gatot, growol, dan thiwul yang tahan disimpan untuk beberapa bulan (tergantung pada baik/tidaknya proses pengolahan yang dilakukan).

Perkembangan produksi ubikayu Indonesia, berdasarkan hasil analisis exponential smoothing_5, sampai dengan tahun 2010 relatif mendatar, namun cenderung ke arah positif. Diharapkan dengan semakin besar kuantitas peningkatannya, maka semakin besar pula peluang ubikayu Indonesia untuk memasuki pasar ubikayu dunia. Walaupun, kuantitas terbesar masih ditujukan untuk pemenuhan kebutuhan domestik, hanya sekitar 22 persen untuk pemenuhan kebutuhan dunia melalui pasar ekspor (Gambar 1).

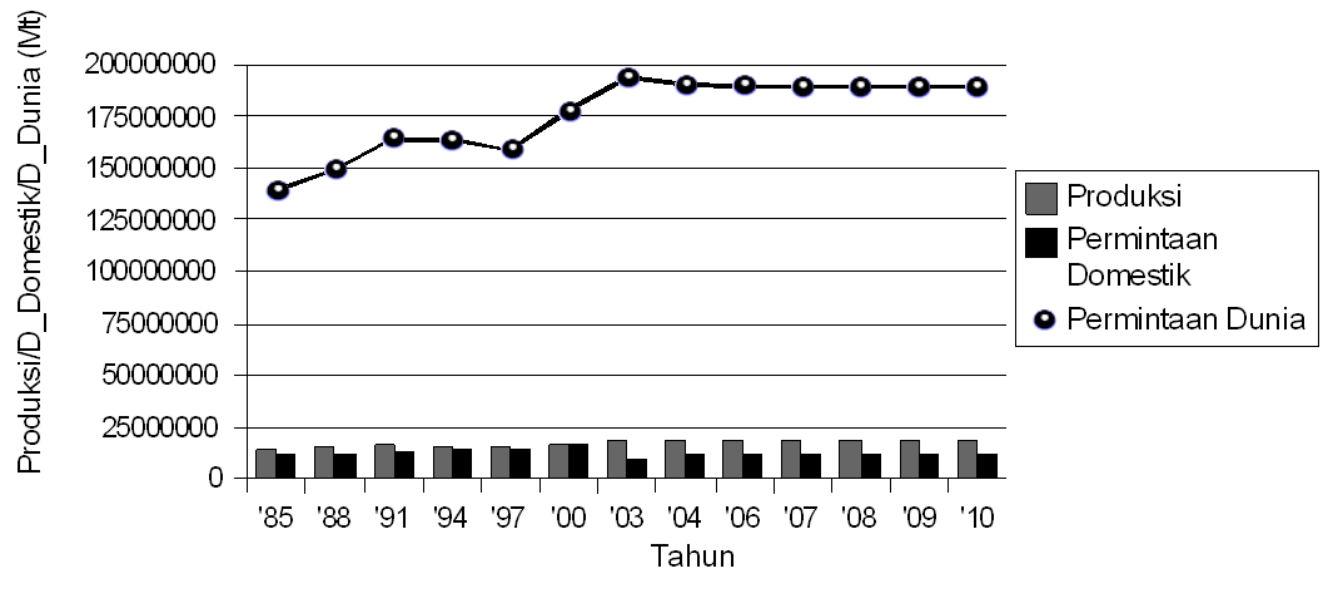

Gambar 1. Perkembangan Produksi Ubikayu Indonesia dan Kebutuhan Pasar Domestik dan Dunia Tahun 1985-2010

Sumber: Faostat 2006, dianalisis.

Peluang tersebut seiring dengan kecenderungan meningkatnya potensi kuantitas ekspor ubikayu Indonesia pada lima tahun yang akan datang. Besarnya potensi ekspor tersebut dapat dilihat dari selisih antara kuantitas produksi terhadap pemenuhan kebutuhan domestik (Gambar 2). 


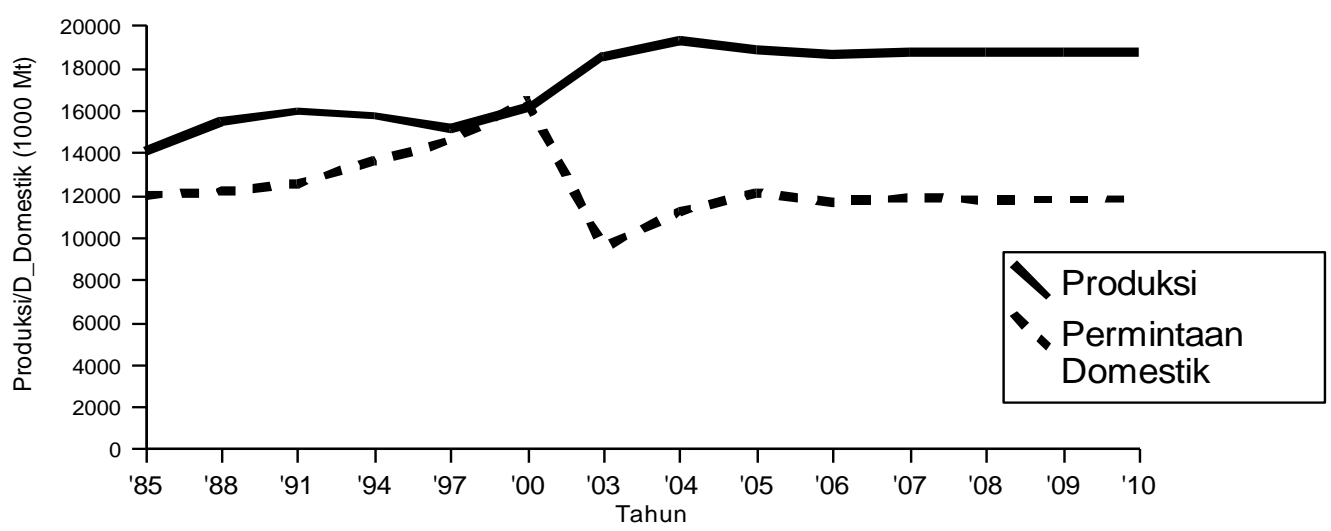

Gambar 2. Potensi Ekspor Ubikayu Indonesia Tahun 1985-2010 Sumber: Faostat 2006, dianalisis.

Perkembangan pemanfaatan ubikayu untuk pemenuhan pasar domestik, sampai dengan tahun 2002, masih didominasi pada pemenuhan kebutuhan pangan (Gambar 3). Dari gambaran tersebut dapat dilihat bahwa image pemanfaatanubikayu di Indonesia masih sebagai komoditas pertanian yang berorientasi pada pemenuhan kebutuhan pangan, belum secara luas direspon sebagai cash crop.

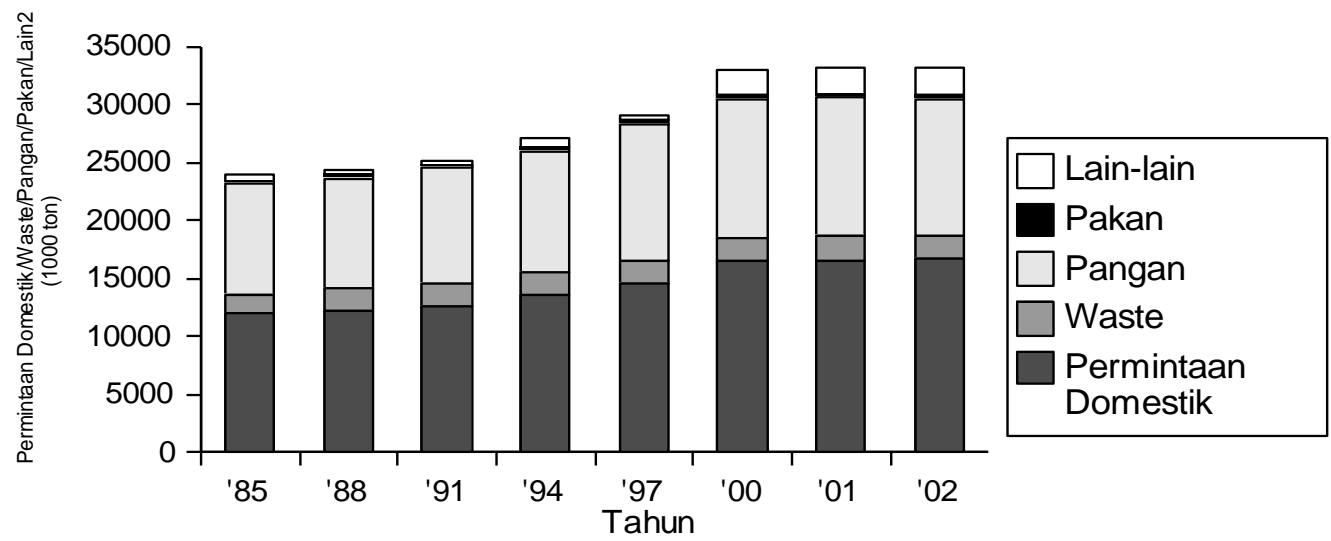

Gambar 3. Alokasi Produksi ubikayu untuk Pemenuhan Kebutuhan Pasar Domestik

Sumber: Faostat 2006, dianalisis. 


\section{PERDAGANGAN UBI KAYU DI PASAR DUNIA}

\section{Perdagangan Ubi Kayu Segar}

Perdagangan internasional untuk ubikayu segar kebanyakan dilakukan hanya terbatas pada transaksi antar negara tetangga dan tidak selalu tercatat secara statistik. Ekspansi tersebut terhambat oleh kondisi ubikayu segar yang bulky dan perishable, yang mengakibatkan produk tersebut sangat berisiko untuk dipasarkan dan menjadi bahan pangan yang tidak terjangkau dan mahal bagi masyarakat perkotaan.

Beberapa tahun terakhir ini terjadi peningkatan pengembangan program intensifikasi perdagangan ubikayu segar dari populasi asli Amerika Latin dan Kepulauan Karibia dan dari Afrika ke berbagai negara maju, seperti Amerika Utara dan Eropa. Ubikayu segar dapat eksis di pasaran melalui penemuan proses pelapisan parafin, atau dalam jumlah lebih sedikit digunakan proses penambahan $\mathrm{CO}_{2}$ pada kantong plastik pembungkusnya, berbagai upaya tersebut dapat memperpanjang dan mempertahankan tingkat kesegaran ubikayu.

\section{Perdagangan Cassava Dried (ubikayu kering/gaplek)}

Pasar ekspor impor untuk cassava dried secara dominan terwakili oleh sektor perdagangan Eropa - Thailand, dan juga termasuk Indonesia. Ekspor CD oleh Thailand mengalami peningkatan setiap tahunnya, dari tidak sama sekali pada tahun 60-an hingga 6 juta ton pada tahun 1978. Sampai dengan 1988 ekspor $C D$ Thailand tidak mengalami perubahan yang berarti, masih sekitar 6 juta ton, namun dari 1988 ke 1992 terjadi perubahan yaitu sekitar 8 juta ton. Sejak tiga tahun terakhir, ekspor $C D$ Thailand ke Eropa mengalami penurunan. Hal tersebut merupakan dampak suksesnya Thailand membuka pasar alternatif untuk CD, yaitu ke China dan Republik Korea.

Studi kasus di Eropa menjelaskan bagaimana politik pertanian masyarakat Eropa membentuk pasar ubikayu. Studi ini disertai fakta-fakta bagaimana perubahan politik masyarakat Eropa dan dunia untuk menghargai proteksi dan perdagangan pertanian, termasuk di dalamnya pasar ubikayu. Banyak saran disampaikan pada saat permintaan Eropa atas $C D$ mengalami penurunan. Namun dengan dengan optimisme yang tinggi Thailand dan mungkin Indonesia (data yang tersedia tidak spesifik) tetap eksis dan kontinue memenuhi kebutuhan $C D$ untuk pasar Eropa dalam jangka panjang. Kondisi ini menciptakan kesempatan yang kecil bagi negara lain untuk ikut masuk ke 
dalam pasar, kecuali anggota WTO dengan kuota 145000 ton, diantaranya adalah Ghana dengan komoditas ekspor cassava dried (FAO dan IFAD, 2004).

Tabel 3. Perkembangan Ekspor Impor Produk Ubikayu Dunia Tahun 1970-2007

\begin{tabular}{|c|c|c|c|c|c|c|c|c|}
\hline \multirow[t]{2}{*}{$\begin{array}{c}\text { Produk } \\
\text { Ubikayu }\end{array}$} & \multicolumn{6}{|c|}{ Tahun } & \multicolumn{2}{|c|}{$\begin{array}{l}\text { Pertumbuhan } \\
\text { per Tahun }(\%)\end{array}$} \\
\hline & & 1970 & 1980 & 1990 & 2000 & 2007 & '70-'07 & ${ }^{\prime} 00-{ }^{\prime} 07$ \\
\hline \multirow{11}{*}{$\begin{array}{l}\text { Cassava } \\
\text { dried } \\
\text { (000 ton) }\end{array}$} & EKSPOR & & & & & & & \\
\hline & Dunia & 1.604 & 6.266 & 9.498 & 3.962 & 6.497 & 9,4 & 9,1 \\
\hline & Thailand & 1.172 & 4.970 & 7.557 & 3.247 & 4.559 & 9,4 & 5,8 \\
\hline & Vietnam & 0 & 0 & 28 & 135 & 1.317 & 40,8 & 125,1 \\
\hline & Indonesia & 334 & 386 & 1.271 & 151 & 210 & 5,3 & 5,6 \\
\hline & IMPOR & & & & & & & \\
\hline & Dunia & 1.398 & 5.261 & 11.410 & 4.773 & 6.783 & 9,9 & 6,02 \\
\hline & China & 15 & 2 & 704 & 257 & 4.672 & 935,1 & 245,4 \\
\hline & Uni Eropa & 1.397 & 5.259 & 8.246 & 3.986 & 1.647 & 4,9 & $-8,4$ \\
\hline & Rep. Korea & 0 & 49 & 763 & 292 & 302 & 35,0 & 0,5 \\
\hline & Jepang & 9 & 11 & 221 & 19 & 27 & 47,5 & 6,01 \\
\hline \multirow{12}{*}{$\begin{array}{l}\text { Cassava } \\
\text { starch } \\
\text { (000 ton) }\end{array}$} & EKSPOR & & & & & & & \\
\hline & Dunia & 5 & 8 & 274 & 983 & 1.572 & 93,2 & 8,6 \\
\hline & Thailand & 0 & 3 & 264 & 906 & 1.422 & 225,6 & 8,1 \\
\hline & Vietnam & 0 & 0 & 28 & 135 & 1.317 & 40,8 & 125,1 \\
\hline & IMPOR & & & & & & & \\
\hline & Dunia & 71 & 120 & 413 & 1.038 & 1.956 & 14,8 & 12,6 \\
\hline & China & 0 & 35 & 220 & 439 & 892 & 19,4 & 14,7 \\
\hline & Uni Eropa & 11 & 13 & 10 & 18 & 68 & 11,8 & 39,7 \\
\hline & Rep. Korea & 0 & 0 & 1,5 & 4 & 35 & 31,8 & 110,7 \\
\hline & Jepang & 50 & 67 & 110 & 116 & 143 & 3,4 & 3,3 \\
\hline & Malaysia & 0,01 & 3,6 & 10 & 87 & 118 & 922,5 & 5,1 \\
\hline & Indonesia & 0 & 0 & 0,002 & 206 & 306 & 257499,2 & 6,9 \\
\hline
\end{tabular}

\begin{tabular}{|c|c|c|c|c|c|c|c|c|}
\hline \multirow[t]{10}{*}{$\begin{array}{l}\text { Tap1oka } \\
\text { (000 ton) }\end{array}$} & $\begin{array}{l}\text { EKSPOR } \\
\text { Dunia }\end{array}$ & 30 & 45 & 21 & 38 & 32 & 1,4 & $-2,3$ \\
\hline & Thailand & 0,2 & 1 & 8,5 & 16 & 0 & 27,4 & $-14,3$ \\
\hline & Indonesia & 0 & 0,5 & 2,8 & 5,5 & 11 & 17,5 & 14,3 \\
\hline & China & 0,01 & 21 & 1,5 & 9,5 & 13 & 5259,8 & 5,3 \\
\hline & $\begin{array}{l}\text { Malaysia } \\
\text { IMPOR }\end{array}$ & 17 & 9,5 & 3,8 & 0,8 & 0,1 & $-7,7$ & $-12,5$ \\
\hline & Dunia & 20 & 58 & 36 & 35 & 50 & 5,3 & 6,1 \\
\hline & China & 21 & 50 & 10 & 5 & 17,5 & 9,1 & 35,7 \\
\hline & Jepang & 0,007 & 0,009 & 0,078 & 0,3 & 1,8 & 44,8 & 71,4 \\
\hline & Malaysia & 1,3 & 0,2 & 3,2 & 1,3 & 2,4 & 36,9 & 12,1 \\
\hline & Uni Eropa & 4,5 & 3,3 & 5 & 1 & 1,5 & 0,4 & 7,1 \\
\hline
\end{tabular}

Sumber: Faostat, 2010.

190 | Putri Suci Asriani. Perdagangan Ubikayu Indonesia di Pasar Dunia 


\section{Perdagangan Cassava Starch (pati ubikayu) dan/atau Tapioka}

Cassava starch atau yang dikenal dengan tapioka sebagai komoditas perdagangan memiliki kemampuan diversifikasi produk yang luas. Ketersediaan data tentang informasi tersebut masih sangat terbatas, termasuk FAO, untuk itu masih diperlukan banyak penelitian. Tetapi, terlepas dari itu, diketahui bahwa lebih banyak importir cassava starch dibandingkan dengan eksportirnya. Hal ini menekankan bahwa tingkat kebutuhan cassava starch sebagai bahan baku industri sangat tinggi.

Thailand merupakan negara pengekspor cassava starch utama dengan kemampuan pemenuhan 85 persen kebutuhan dunia. Pada tahun 1990, tercatat sekitar 85 persen impor cassava starch dunia dilakukan China dan Jepang. Pada tahun 1995, tercatat sekitar 81 persen impor cassava starch dunia dilakukan oleh China, Indonesia, Malaysia, dan Jepang (Faostat, 2010).

Studi kasus yang dilakukan untuk pasar pati Eropa dan Amerika Utara, menggambarkan fakta bahwa selera konsumsi patikedua bangsa tersebut didasarkan pada kelebihan penawaran atas ketersediaan bahan baku. Selera konsumsi pati di Eropa sangat dipengaruhi oleh kondisi geografi regional. Patikentang, gandum, dan jagung lebih disukai dibandingkan dengan pati ubikayu. Dalam jumlah relatif besar, impor atas komoditas kentang, gandum, dan jagung dipenuhi oleh China dan Jepang. Sehingga terlihat bahwa Eropa dan Amerika Utara merupakan pasar cassava starch yang besar untuk pemenuhan industri bahan perekat (adhesive) dan minuman. Pada saat harga jagung dan pati jagung tinggi, industri kertas di Amerika Utara mengimpor cassava starch dalam jumlah besar (FAO dan IFAD, 2004).

Studi lainnya yang dilakukan untuk pasar pati di Brazil, Eropa, Amerika Utara, dan Thailand menggambarkan adanya potensi pertumbuhan kebutuhan cassava starch termodifikasi. Negara-negara tersebut melakukan pembangunan secara komersial untuk memproduksi patitermodifikasi dengan produsen Eropa dan Amerika Utara. Studi ini juga mengindikasikan bahwa secara eksklusif suatu negara memproduksi ubikayu yang diproses menjadi patitermodifikasi untuk pemenuhan kebutuhan dalam negeri.

\section{SITUASI PASAR DAN POTENSI PENGEMBANGANNYA}

Di banyak negara berkembang, selain Thailand, Vietnam dan Indonesia, ubikayu sangat jarang diperdagangkan dan/atau diperdagangkan secara tidak formal. Keterbatasan jaringan pemasaran yang tersedia, kurangnya infrastruktur, lemahnya informasi pasar dan tidak menentunya penawaran serta 
kualitas bahan baku ubikayu merupakan faktor kendala perdagangan ubikayu. Sebagai tambahan, keunggulan kompetitif Thailand merupakan sebuah tantangan yang menakutkan bagi negara-negara yang mengharapkan terjadinya penetrasi pasar internasional.

Pada cakupan yang lebih luas, perdagangan ubikayu pada masa yang akan datang akan tergantung pada faktor kelembagaan; khususnya pada kebijakan yang diimplementasikan oleh negara-negara importir utama. Pada saat harga domestik biji-bijian di pasar Uni Eropa diperhitungkan pada batas kompetitif diimpornya pakan ternak berbahan ubikayu, maka eksportir cassava dried akan menganjurkan untuk mencari pasar alternatif atau menetapkan ketersediaan penawaran produk pada harga yang lebih murah.

Perdagangan pada tingkat regional dapat dipromosikan melalui pengembangan proses pengolahan lokal, penetapan sistem informasi pasar dan promosi jangkauan pasar baru dengan spesialisasi produk. Sifat bulky dan perishable pada ubikayu mengakibatkan meningkatnya biaya transportasi dan pemasaran, serta membuat produk relatif mahal di wilayah perkotaan, sehingga berdasarkan kendala-kendala tersebut pengembangan industri pengolahan ubikayu di arahkan mendekati wilayah pusat produksinya. Lebih dari itu, konsumsi masyarakat di wilayah perkotaan dapat dijadikan stimulasi ke arah diversifikasi peningkatan nilai tambah produk-produk berbasis ubikayu yang baru, seperti roti, biskuit, mie, kue-kue, makanan bayi dan bahan pemanis.

Dengan meningkatnya pertumbuhan migrasi penduduk, permintaan bahan pangan berbasis ubikayu kemungkinan juga meningkat di berbagai negara maju, sebagaimana yang telah terjadi di Eropa dan Amerika Utara. Selanjutnya, di wilayah tersebut, diindikasikan bahwa komunitas "bukan etnis" yang merupakan pendatang sangat tertarik pada bahan pangan "eksotis" seperti ubikayu. Kelemahannya adalah mayoritas pasar komunitas "bukan etnis" tersebut tidak mengetahui apa itu ubikayu, atau bagaimana mempersiapkan bahan berbasis ubikayu tersebut. Jika kekhususan pasar tersebut dan tentu saja juga pada pasar lainnya berkembang, maka berbagai produk berbasis ubikayu perlu dipromosikan.

Penggunaan ubikayu sebagai input industri, khususnya etanol akan tergantung pada ketersediaan dan tingkat kompetitif harga terhadap berbagai produk alternatif seperti jagung. Jika para pelaku usaha pengembangan produk berbasis ubikayu berharap memperluas jangkauan pasarnya, baik domestik maupun internasional, maka kompetisi tersebut diantisipasi pada pertumbuhan tahap menengah, di mana bagi produsen dan industri pengolah ubikayu akan 
ditetapkan tingkat produksi optimalnya dengan biaya rendah. Seiiring dengan hal tersebut, China menerapkan upaya menjaga keberlanjutan produksi etanol berbasis ubikayunya melalui penetapan investasi berskala besar bagi negara yang memiliki program pengembangan sektor produksi ubikayu penunjang pasar internasional. Sebagai tambahan, prospek program biofuel di berbagai negara secara global dapat menghantarkan ubikayu ke potensi pertumbuhannya yang signifikan, terutama ketika program tersebut didasarkan pada permintaan yang disampaikan, dan pada akhirnya akan dapat menyediakan aliran akses pasar ubikayu yang lebih baik.

\section{PERAN WTO DALAM PERDAGANGAN UBIKAYU DI PASAR DUNIA}

Keuntungan yang diperoleh dengan adanya globalisasi adalah menggeser atau mendistribusikan produk ubikayu dari negara-negara produsen ke pasar-pasar potensialnya. Beberapa komoditi telah mengalami proses transfer produksi pangan ke negara-negara pasar potensialnya, diantaranya adalah ubikayu. Secara global ubikayu merupakan tanaman pangan bagi lebih dari 500 juta orang, sumberdaya utama ketahanan pangan dan tanaman pangan komersial yang baik, namun penggunaannya cenderung kompetitif hanya pada pemenuhan kebutuhan pasar pati global. Pati ubikayu (cassava strach) berkompetisi dengan pati (starch) dari jagung, gandum, dan kentang.

Ubikayu dibudidayakan sebagai penghasil pati, umbi(akar)nya diproses menjadi tapioka. Secara keseluruhan ubikayu diproduksi untuk menghasilkan bahan pangan berbasis ubikayu ( Brazilian arrowroot) yang digunakan sebagai bahan pakan ternak atau dimasak dan dimakan sebagai sayur-sayuran. Pada tahun 2002, Nigeria merupakan produsen ubikayu terbesar di dunia. Tetapi di tahun 2003 mengalami penurunan sehubungan dengan kondisi cuaca yang terjadi di negara tersebut, sehingga terjadi serangan penyakit tanaman ubikayu.

Eksportir utama ubikayu dunia adalah Thailand, secara agregat komoditas ekspornya adalah ubikayu kering (dry cassava) - juga dikenal sebagai tapioka - dalam bentuk pellets guna peruntukan industri pakan ternak di USA dengan tingkat tarif rendah yang didasarkan pada kuota.

Indonesia sebagai eksportir ketiga ubikayu dunia yang juga merupakan anggota WTO menganut sistem ekonomi terbuka sehingga keterkaitan pasar domestik dengan pasar dunia (global) menjadi sulit dihindarkan, termasuk untuk pasar ubikayu. Masalahnya, dengan tekanan liberalisasi yang semakin kuat bagaimana pemerintah dapat memanfaatkan peluang pasar global untuk 
mendukung kontinuitas pemasaran ubikayu Indonesia dengan menghindari kemungkinan dampak negatif pengaruh liberalisasi terhadap produsen ubikayu di dalam negeri.

Setelah World Trade Organization (WTO) terbentuk dengan sifat permanen dan berkedudukan setara dengan International Monetary Funds (IMF) dan Bank Dunia. Terbentuknya WTO juga telah memberikan harapan kepada masyarakat internasional akan adanya suatu lembaga multilateral yang mengatur sistem perdagangan internasional, dengan aturan yang lebih jelas dan komprehensif serta mekanisme penyelesaian sengketa dagang yang efektif. WTO diharapkan akan mampu menciptakan transparansi kebijakan perdagangan setiap negara anggota bagi anggota yang lain, sehingga semua negara anggota dapat memperkirakan dampak yang mungkin akan timbul akibat penerapan kebijakan tersebut.

\section{KEBIJAKAN PERDAGANGAN UBIKAYU INDONESIA MASA MENDATANG}

1. Kegunaan potensial dari ubikayu sebagai bahan baku industri manufaktur sejauh ini menarik bagi banyak wilayah, namun hanya Thailand yang menunjukkan kemajuan pengembangan industri pati ubikayu yang baik dan maju guna memenuhi kebutuhan pasar domestik dan ekspor. Dikarenakan tingginya tingkat proteksi dan kompleksitas pasar pati internasional, maka produsen pati ubikayu diharapkan mampu menemukan banyak alternatif pengembangan dan pemasaran produk di pasaran domestik dan ekspor.

2. Di banyak negara berkembang, selain Thailand, Vietnam dan Indonesia, ubikayu sangat jarang diperdagangkan dan/atau diperdagangkan secara tidak formal. Keterbatasan jaringan pemasaran yang tersedia, kurangnya infrastruktur, lemahnya informasi pasar dan tidak menentunya penawaran serta kualitas bahan baku ubikayu merupakan faktor kendala perdagangan ubikayu. Perdagangan ubikayu pada masa yang akan datang sangat tergantung pada faktor kelembagaan; khususnya pada kebijakan yang diimplementasikan oleh negara-negara importir utama. Untuk perdagangan di tingkat regional, masih dapat dipromosikan melalui pengembangan proses pengolahan lokal, penetapan sistem informasi pasar dan promosi jangkauan pasar baru dengan spesialisasi produk.

3. Sifat bulky dan perishable pada ubikayu mengakibatkan meningkatnya biaya transportasi dan pemasaran, serta membuat produk menjadi relatif mahal di wilayah perkotaan, sehingga berdasarkan kendala-kendala tersebut 
pengembangan industri pengolahan ubikayu di arahkan mendekati wilayah pusat produksinya. Konsumsi masyarakat di wilayah perkotaan dapat dijadikan stimulasi ke arah diversifikasi peningkatan nilai tambah produkproduk berbasis ubikayu yang baru dan berbagai produk berbasis ubikayu tersebut perlu dipromosikan. Untuk pemanfaatan ubikayu sebagai input industri, khususnya etanol, akan tergantung pada ketersediaan dan tingkat kompetitif harga terhadap berbagai produk alternatifnya.

4. Secara strategis ekonomi upaya pengembangan ubikayu di Indonesia adalah layak dilakukan untuk pemenuhan kebutuhan pasar ekspor dan domestik. Namun, mengacu pada berbagai kendala dan alternatif diversifikasi pola perdagangan internasional yang memungkinkan untuk diakses produkproduk berbasis ubikayu dari Indonesia, maka diperlukan beberapa pendekatan model pemasaran ubikayu yang diharapkan mampu berimplikasi pada kebijakan perubikayuan Indonesia.

5. Penetapan model pemasaran ubikayu di pasar internasional tersebut secara simultan berkaitan sangat erat pada bagaimana model konsumsi ubikayu Indonesia, baik yang berasal dari impor maupun yang digunakan untuk pemenuhan kebutuhan pasar ekspornya; untuk setiap spesifikasi produk yang diperdagangkan, baik di pasar ekspor maupun impor, perlu diketahui berapa tingkat keunggulan komparatif dan kompetitifnya melalui pengembangan model daya saing; pengiriman produk ekspor maupun penerimaan produk impor berbasis ubikayu harus melalui saluran pemasaran yang efisien, sehingga perlu ditelusuri integrasi pasar ekspor impor-nya guna diperoleh posisi leader market ubikayu Indonesia yang menguntungkan.

\section{DAFTAR PUSTAKA}

Balagopalan, C. 2002. Cassava Utilization in Food, Feed, and Industry. (C)AB International (Cassava: Biology, Production and Utilization): 301-318.

Deptan RI, 2009. Database Deptan. (http://www.deptan.go.id). Akses terakhir Feb. 2010.

Direktorat Perdagangan, Perindustrian, Investasi, dan HAKI; Direktorat Jenderal Multilateral Departemen Luar Negeri, 2009. Sekilas WTO (World Trade Organization) Edisi V. Jakarta.

Eng, Pierre Van Der. 1998. Cassava in Indonesia: A Historical Re-Appraisal of an Enigmatic Food Crop. Southeast Asian Studies 36 (1): 3-31. 
FAOSTAT, 2010. FAO. Rome: Italy (http://faostat.org). Akses terakhir Februari 2010.

FAO and IFAD, 2004. Proceedings of The Validation Forum on The Global Cassava Development Strategy (Volume 6): Global Cassava Market Study Business Opportunity for the use of Cassava. FAO. Rome.

FAO and IFAD, 2001. Proceedings of The Validation Forum on The Global Cassava Development Strategy (Volume 1): The Global Cassava Development Strategy and Implementation Plan. FAO. Rome.

Goletti, F., Karl Rich and Chris Wheatley, 2001. The Cassava Starch Industry in Vietnam: Can Small Firms Survive and Prosper? International Food and Agribusiness Management Review 2(3/4): 345-357.

Gunawan, M. 1997. Market Prospects for Upland Crops in Indonesia. Working Paper Series. Head Publication Section CGPRT centre. Bogor.

Howeler, Reinhardt. 2000. Cassava in Asia: Present Situation and its Future Potential in Agro-Industry. Proceeding The $6^{\text {th }}$ Regional Cassava Workshop, Vietnam: 1-36.

IFAD. 2003. Cassava-A Market Research Study (Market Analysis and Strategy Recommendations). Langmead \& Baker Ltd. Zambia.

IFAD and FAO. 2000. The World Cassava Economy (Facts, trends and outlook). International Fund for Agricultural Development Food and Agriculture Organization of the United Nations. Rome.

Prakash, Adam, 2004. Cassava: Internastional Market Profile. Trade and Markets Division. Food and Agriculture Organisation of the United Nations.

Saleh, N., Koes Hartojo, and Suyamto, 2000. Present Situation and Future Potential of Cassava in Indonesia. Proceeding The $6^{\text {th }}$ Regional Cassava Workshop, Vietnam: 47-60.

Schuh, G.E., 1991. Open Economics: Implication for Global Agriculture.American Journal of Agricultural Economics 73(5): 1322-1329.

Sriroth, K., C. Rojanaridpiched, V. Vichukit, P. Suriyaphan, and C.G. Oates, 2000. Present Situation and Future Potential of Cassava in Thailand. Paper presented at The $6^{\text {th }}$ Regional Cassava Workshop, Vietnam:

Wang, Wenquan, 2000. Cassava Production for Industrial Utilization in China Present and Future Perpective. Proceeding The $6^{\text {th }}$ Regional Cassava Workshop, Vietnam: 33-38

World Trade Organization. 1994. The Result of the Uruguay Round. WTO. Jenewa.

Yinong, Tian., Lin Xiong and Jin Shuren, 2000. Present Situation and Future Potential of Cassava in China. Proceeding The $6^{\text {th }}$ Regional Cassava Workshop, Vietnam: 71-83. 